\title{
Article
}

\section{On firm Carthaginian ground: ethnic boundary fluidity and Chaucer's Dido}

\author{
Randy P. Schiff \\ Department of English, University at Buffalo, The State University of New York, \\ Buffalo, NY.
}

\begin{abstract}
Rome's genocidal destruction of Carthage reveals profound anxiety concerning Phoenician culture. A dynamic maritime empire whose merchant-sailors regularly assimilated themselves into various locales, Carthage generated considerable ethnic instability in the Mediterranean. Roman poets systematically reduced Carthaginian difference to its founder-queen Dido's trauma, consigning Phoenician culture to the past. Removing the story of Dido's diasporic leadership, and misidentifying her realm as a generalized Libya, Chaucer prolongs Rome's anti-Punic campaign. Presenting Dido as a pitiful lover who ignominiously dethrones herself for Aeneas, Chaucer also aestheticizes Rome's reduction of Carthaginian dynamism into a desert.
\end{abstract}

postmedieval: a journal of medieval cultural studies (2015) 6, 23-35.

doi:10.1057/pmed.2014.42

Phoenicians have perennially figured anxieties about ethnic instability. Meditating on the impossibility of sorting out ethnic lines in a Mediterranean buzzing with interpenetrating cultures, the poet Charles Olson turns to a Phoenician (Olson, 1983, 274). It is only after invoking Sanuncthion, a 'self-conscious historian' who 'existed in,/and as of Phoenicia' that Maximus can attempt to describe the 'hub-bub/of peoples' that includes Libyans, 'unknown Raiders/of the Sea,' Hittites, Hurrians, Sumerians, Persians, Egyptians, various Indo-Europeans 
and Ugandans (Olson, 1983, 274-275). With their seafaring ways invoked in the previous poem by Ousoos, the first person to 'carve out' a tree and 'go out/on the waters,' Phoenicians aptly inaugurate a poetic history of the Mediterranean's dizzying ethnic diversity that can conclude only with a question mark (Olson, 1983, 273, 275).

The Roman response to the ethnic mobility and maritime dynamism of the Carthaginians, antiquity's most prominent Phoenicians, was violently different from Olson's poetic fascination. In the annals of Western violence, the Roman destruction of Carthage stands out as both cruel and foundational. Ben Kiernan argues that Rome's annihilation of Carthage in the Third Punic War set the Western 'precedent' for deliberate military genocide (Kiernan, 2007, 58). That Rome's actions were overdetermined, driven by deep-seated anxieties about their Mediterranean neighbors, is suggested by the fact that no immediate military or economic threat inspired the statesman Cato's grisly public refrain, 'Carthago est delenda' ('Carthage must be destroyed') (Kiernan, 2007, 53). Long-held economic, geographical and cultural fears clearly converged in a perfect Roman storm. If race is, as Geraldine Heng maintains, a purely 'instrumenta[l]' quality whose 'function' is determined by 'historical' context, with religious or communal identity as potentially salient as 'phenotype,' then racialization haunts Rome's eradication of Carthaginian civilization (Heng, 2003, 13-14, emphases in original). Race, as a 'cultural fantasy' that nevertheless maintains a 'material' essence both through its historical origins and its conditioning of state and individual actions, powerfully contextualizes Romans' influential discomfort with Phoenicians (Heng, 2003, 14).

The hatred of Phoenicians that drove Scipio the Younger's armies, while connected to long-standing tension between the Roman and Carthaginian states, was also played out in literary history - an environment that vividly illuminates race's status as fantasy (Goldsworthy, 2006, 350-368). Henry Louis Gates, Jr's seminal insight that race is a 'trope' illuminates how Rome's path toward genocide was laid, in part, by rhetoric (Gates, 1985, 5). Cato's discursive portrait of Phoenicians linked their sea travel with dangerous intermingling. For Cato, a devoted ethno-historian who composed genealogies of Italian tribes, Phoenicians were a toxic foreign presence: the shiftless Phoenician 'mercatorem' ['trader'] from across the sea threatened the fundamentally agricultural culture of Rome, whose 'viri fortissimmi' ['best men'] came from the 'agricolus' ['farming class'] (Cato and Varro, 1935, 2-3; Kiernan, 2007, 49-54). Nostalgically portraying Romans as farmers rooted in their native Italian soil, Cato channeled knowledge of Carthage's maritime dynamism into a fatally xenophobic fantasy of shifty Phoenicians corrupting an upright Rome.

Cato's vile rhetoric depended not only on Roman fears that Carthage might regain its commercial preeminence in the Mediterranean, but also on cultural fantasies linking Carthaginians with their legendary 'Semitic' founder, Dido (Goldsworthy, 2006, 26). Dido's literary historical legacy, I shall argue, clarifies 
why Carthaginian culture seemed so menacing to Rome. Concentrating anxieties about what Fredrik Barth calls ethnic 'boundary' crossing, Dido served Roman poets as a conduit for anti-Punic energies generated by Phoenicians' thriving maritime trade (Barth, 1998, 132). Roman fascination with Dido in foundational literary texts such as the Aeneid reveals awareness that Roman culture also depended upon ethnic fluidity. However, Roman poets turned to Dido to feminize a Carthaginian empire that embraced the benefits of widely dispersed settlement and assimilation, while portraying their own racial mobility as limited to male warriors acting under emergency conditions.

I shall argue that Geoffrey Chaucer channels such anxiety about Phoenicians as he asserts his place in a Roman-centered Western tradition. Chaucer clearly links his literary ambition with Rome by choosing Romans for four of the five authors who grace the 'steppes' that the narrator of Troilus and Criseyde bids his book kiss (V.1791-1792). ${ }^{1}$ Chaucer's self-identification with Rome also emerges through a network of dream-vision images that contrast his modernity with Carthage. Much as María Rosa Menocal demonstrates literary historians' tendency to write Arabic Islamic influence out of self-defining Western narratives, we should also recognize earlier repression of the Semitic Other in Rome's extended anti-Punic campaign (Menocal, 1987, 1-16). Despite its deep cultural roots alongside Greeks and Romans in such regions as North Africa, Iberia, Sicily, the Levant and Cyprus, Phoenician identity remains marginalized in Western literary history - and Chaucer participates in this originally Mediterranean cultural clash (Markoe, 2000, 14-66, 182-186; Goldsworthy, 2006, 26-36).

Juxtaposing his poetic self-portraits with Rome's dismantling of Carthage, Chaucer turns to Dido to weave his Phoenician fantasy. In the Legend of Good Women, Chaucer responds to Romans' perennial fear of Phoenician mobility by grounding Dido in a timeless Africa. Removing any mention of Dido's maritime journey, while situating her in an only vaguely identified Libya, Chaucer denies Carthage what Johannes Fabian calls 'coeval' status with Rome. ${ }^{2}$ In the House of Fame, Chaucer aestheticizes Carthage's destruction, sublimating the results of Rome's genocidal campaign into the wasteland visited after Venus's Didodecorated temple. Finally, in the Parliament of Fowls, Chaucer imagines the pair of Scipios intimately connected with Carthage's destruction, as the poem both invokes and exorcises the specter of Phoenician influence in the West.
1 All citations from Chaucer's works are from the Riverside edition, eds. Benson et al. (1987), by line numbers.
2 On Western anthropologists' tendency to deny 'coevalness' to their subjects, situating them in an alternative, primitive time, see Fabian (1983, 31).

\section{Identity in a Fluid Mediterranean}

Exploring nineteenth-century racial historiography, Martin Bernal demonstrates that images of Phoenicians as distinctly Eastern helped consolidate Western exceptionalism (Bernal, 1987, 337-399). However, the Roman perception of Phoenicians differed strikingly from the Romantic discourses studied by Bernal. 
3 On Phoenicians' reputation as travelers, see Picard and Picard (1969, 87-100) and Aubet (2001, 97-143).
Whereas these nineteenth-century writers deployed a primarily biological model of race, according to which valorous, reasonable and freedom-loving 'Aryan' Westerners struggled continuously with violent, passionate and religious 'Semites' such as the Phoenicians, Roman stereotyping of Phoenicians highlighted the habits of mobility and intermingling associated with maritime commercial culture (Bernal, 1987, 340-359). Recalling that racial 'fantasy' reveals its 'material' origins as it 'confronts history,' we should first establish how and why Phoenicians unsettled Romans (Heng, 2003, 14).

The fluid nature of Mediterranean ethnic identity contextualizes Roman sensibilities about dangerous Phoenician difference. Much as scholars of medieval Mediterranean Studies caution against mapping the region according to clear ethno-national lines, so do historians of Romano-Punic conflict regularly foreground the region's fluctuating and overlapping interests and allegiances (Kinoshita, 2009, 600-602). Although Phoenicians were not the only people whose commercial and military movements created ethnic instability, Phoenician travelers were linked in the very foundations of Western historiography with dangerous crossings: according to Herodotus, the Phoenician merchants who

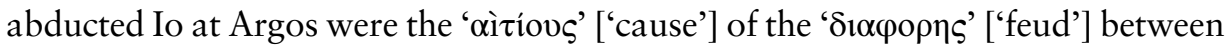
the West and Asia that produced the Trojan and Greco-Persian wars (Herodotus, 1990, 2-7). ${ }^{3}$ Such stereotyping responds to Phoenician dynamism: their numerous trading networks contributed significantly to the sense of ethnic instability against which a resolute Roman identity politics was mobilized (Markoe, 2000, 95-106; Aubet, 2001, 97-143).

Rome and Carthage were initially partners: mutually threatened by Greek colonization in the Western Mediterranean, they formed an alliance that displaced older Etrusco-Punic ties (Picard and Picard, 1969, 182-187). As it soon became more than just a North African base for Phoenician seafarers, acquiring both a stable state and a stranglehold on many Mediterranean trade routes, Carthage came into direct conflict with Rome (Picard and Picard, 1969, 88-100; Casson, 1991, 61-67). By the sixth-century B.C.E., Carthage's Magonid dynasty had negated Libyan pressures and exploited the loosening grip of Persian overlordship of Phoenician holdings, and by the fifth-century B.C.E Carthage had replaced its mother-city Tyre as the premier Phoenician city (Picard and Picard, 1969, 103; Markoe, 2000, 61-63). Although Phoenician culture had since at least 1000 B.C.E. been spreading its influence in Spain, Sicily, Sardinia, Tunisia, Morocco and mainland Italy, Carthage had fast become the center for Phoenicians' centrifugal settlement patterns - and a nervous Rome took notice (Aubet, 2001, 194-211).

What soured the Romano-Punic partnership was a fundamentally different approach to empire. While Rome developed an expansionist and centralizing military state that systematically absorbed mainland Italic neighbors, the Carthaginians cultivated diffuse trade networks and limited most settlements to ports and mining areas (Picard and Picard, 1969, 88-100; Markoe, 2000, 
102-107). By the 264 B.C.E. opening of the First Punic War, Carthage's colonies in Iberia, Sicily, Sardinia and Italy constituted a powerfully attractive ethnic empire, with immigrants setting up shop throughout the Western Mediterranean. Carthaginian culture presented not just military but existential threats. The Romans were masters at using state power to assimilate various peoples, impelling Campanians, Ligurians and other Italian tribes to look to Rome for identity (Crawford, 1986, 27-32). The Carthaginian empire was Rome's most significant competitor in the trans-Mediterranean struggle for loyalties. Roman unease about the integrity of its own ethnic identity can be seen most clearly during the Second Punic War, during which seventeen-year conflict Hannibal's wildly successful campaigns drew much of southern Italy and Sicily into the Carthaginian fold (Goldsworthy, 2006, 220-224).

Barth's concept of ethnic boundary crossing, which accords with race conceived as material fantasy, clarifies Rome's anxiety concerning the dynamic, scattered nature of Phoenician assimilation and expansion. Exploring identity in Afghanistan's borderlands, Barth focuses not on objective content, but on the fluid boundaries through which ethnic identities are continually constructed (Barth, 1998, 117-134). Resisting positivist enumeration of enduring racial groups, Barth does not ignore skin color, but rather subordinates potential markers of difference to a more general ethnic collation of essentially unstable criteria. Changes in cultural parameters ensure that ethnic groups mutate over time; when individuals are capable of traversing ethnic boundaries to find more attractive socio-material circumstances, ethnicity emerges as not static, but rather as constantly conditioned by fluid social and economic factors (Barth, 1998, 132-134).

While Barth does not focus on intermarriage and interbreeding, such patent cases of ethnic boundary crossing are prominent in literary depictions of racial instability. It is crucial to recognize that Roman literature prominently features stories of ethnic assimilation, making Roman hostility to Phoenician boundary crossing a question of style rather than substance. The Romans represented ethnic assimilation as something they practiced only under emergency conditions, and always with a sense of male Roman aggression against passive women. Two foundational stories illustrate this masculinist Roman model. Romans' very viability as an ethnicity depended upon Romulus, who, faced with a demographic emergency when a lack of Roman women was coupled with neighboring tribes' refusal to intermarry, organized the rape of the Sabine women (Livy, 1925, I.ix.1-xiii.6). In an equally seminal legend, Aeneas established the line of proto-Roman kings by marrying Lavinia, whose violent wooing takes up the latter half of the Aeneid (Virgil, 1935, VII.1-XII.952). Romans thus recognized ethnic boundary crossing as inevitable, but they carefully channeled it into expressions of masculine military dominance - and this gendered understanding illuminates why they found so unsettling Dido's very different, Phoenician approach. 


\section{Dido and Dangerous Phoenician Difference}

4 On medieval race as combining aspects of gender, sexuality, politics, theology, geography and corporeality, see Cohen (2003, 190-199), Hahn (2001, 1-37) and Heng (2003, 70-71).

5 Cato wanted 'women kept in their place' as much as Phoenician 'traders' (Kiernan, 2007, 55).
Recognizing that Carthage's growth threatened its own Mediterranean preeminence, Rome systematically vilified Phoenicians in a racial project that featured Dido. Considering the jostling of skin, sex, geography and other aspects of racial identity's 'multiple category overlap, ${ }^{4}$ we should not be surprised that classical anti-Punic rhetoric was often gendered (Cohen, 2003, 193)..$^{5}$ In a long-term literary campaign aimed at consolidating the destruction of Carthaginian influence, Romans both racialized and sexualized a threatening East (Desmond, 1994, 32-33). In the figure of doomed Dido, Romans projected their nervousness about the dangerous mobility of an attractive Semitic other.

Roman poets were active in ethno-historiographically reducing Phoenician difference to Dido's story. Virgil traces Romano-Punic hostilities to abandoned Dido's curse when she urges her fellow 'Tyrii' ['Tyrians'] forever to hate Aeneas's 'stirpem et genus' ['stock and race'], making 'litora litoribus contraria' ['shore with shore clash'] (Virgil, 1935, IV.622-629). Partisan ethno-historiography also shapes Silius Italicus's first-century C.E. Punica. Juno, determined to provide for Dido's 'profugis' ['exiles'] an 'aeternam . . . gentem' ['nation to last forever'] on the 'fatali . . . Libyes . . . orae' ['destined shore of Libya'], becomes enraged at hearing of Trojan Aeneas's founding of an Italian kingdom (Silius, 1934, I.2328). Juno inspires the 'Phoenicum' ['Phoenicians'] with 'bellandi corda furore' ['frenzy for war'], initiating the First Punic War, in which Rome first faces and defeats Carthage (Silius, 1934, I.29-37; Goldsworthy, 2006, 65-140). Silius's ethno-historical emphasis is clear from the epic's strained chronology; joining Virgil in anachronistically synchronizing Aeneas's and Dido's periods of exile, Silius magnifies his temporal hubris by implying that the third-century B.C.E. First Punic War followed directly upon Aeneas's twelfth-century B.C.E. foundation of a proto-Roman kingdom. Eschewing the limitations of diachronic history, Silius and Virgil produce synchronic visions of ongoing ethnic struggle between Romans and Phoenicians.

The story of what Marilynn Desmond calls the 'historical' Dido - a somewhat misleading term, since it is hardly less literary than Virgil's version - illuminates why Dido, as a cunning manager of ethnic boundaries, both fascinated and disturbed the Romans (Desmond, 1994, 24). The 'historical' Dido's legend dates from at least the fourth-century B.C.E, with Justin's second-century C.E. epitome of Pompeius Trogos's Augustan version available to Chaucer through Augustine's and Boccaccio's retellings (Desmond, 1994, 24-27, 238-239). In Justin's story, Dido is a Phoenician princess married to Acerbas (or Sychaeus), a priest of Melqart. After her brother Pygmalion becomes king and murders her husband, Dido convinces a number of Tyrian nobles and sailors to sail off with her. She craftily seals their loyalty by feigning to sacrifice treasure, which she stows away to fund her land-buying enterprise. Dido's island-hopping journey shadows well-worn Phoenician trade networks and settlement patterns. 
Crucially, Dido stops on Cyprus, an island associated with Venus and sexuality, and also the location of Kition and Qart-hadasht, two Phoenician colonies tied to the lucrative copper trade from which Cyprus derives its name (Markoe, 2000, 170-172; Boccaccio, 2001, 38-43). ${ }^{6}$ Assuming management of both her people's population and spirituality, the 'historical' Dido picks up a number of Cypriot young women - 'ad solatium iuventutis et prolem procreadam' ('to comfort the young men and for purposes of procreation'), explains Boccaccio - along with a 'priest of Jupiter' (Boccaccio, 2001, 170-171; Justinus, XVII.5). Once on African soil, Dido deceives the locals by buying an ox-hide's worth of land; she then cuts it into such thin strips that she acquires enough space to build Carthage. Renowned for her building program and law-giving, Dido soon finds herself tricked into agreeing to marry Ierbas, a Numidian royal suitor. Choosing death rather than unwanted marriage, Dido - like many a Carthaginian general, and like many desperate Carthaginians during Rome's final act of genocide (Picard and Picard, 1969, 80, 108, 159, 285) - kills herself (Justinus, 1853, XVII.3-6; Desmond, 1994, 24-26).

Both Ovid and Virgil preserve details of Dido's harrowing ethno-genetic journey. In the Heroides, Ovid moves from Dido's self-condemnation for having betrayed her late husband Sychaeus to her recounting of her 'exul' ['exile'] and consequent foundation of Carthage (Ovid, 1914, VII.98, 115-120). Virgil's suicidal Dido also bemoans her broken vows, while Ierbas appears as a frustrated suitor upset that a sweet-talking, nattily dressed Trojan won Dido's heart (Virgil, 1935, IV.550-552, 534-536). Virgil's Aeneas mentions Dido's Phoenician identity precisely when ethnic borders are threatened: reminding Dido that she followed her desire for a new homeland, Aeneas suggests that if she, a 'Phoenissam,' came to Africa, then she should not complain if Trojans yearn to reach Italy (Virgil, 1935, IV.347-350, 418-419). Dido's Phoenician identity is here a historically accurate touch, avoiding the term 'Punic' that her very foundational activity enabled - for only after centuries of intermarriage and immigration could Dido's original fleet of Tyrians, Sidonians and Cypriots develop into a distinctly Carthaginian culture (Markoe, 2000, 92).

Tracing Romano-Punic conflict to Dido, Virgil clearly recognizes her as a powerful founder-figure who boldly constructed a challenging, attractive empire. Virgil's insistence on reducing Carthaginian culture to Dido's trauma helps manage a cultural threat by denying Phoenicians coeval status. Carthaginian destiny is reduced to a single, fruitless and distinctly past effort to avenge its founder-queen. ${ }^{7}$ Such strategic use of racial fantasy responds to the sense that, because it had long destabilized ethnic boundaries throughout the Mediterranean, Phoenician identity threatened Rome's ethnic integrity. Besides notorious ethnic boundary crossings like the Italic tribesmen turning Carthaginian during Hannibal's era, other evidence exists of Roman anxiety about its population's integrity, such as Romano-Punic treaties that allowed Carthaginian pirates to enslave Italic men, but not the women or children who could more readily
6 Cyprus significantly oriented Punic culture, for its commercial and cultural importance ensured that Carthage maintained 'Eastern' sensibilities, despite intense Hellenization (Markoe, 2000, $32,166,170)$.

7 For analysis of Fabian's concept of coevalness and political uses of periodization schemes, see Davis (2008, 2-3). 
generate demographic change (Picard and Picard, 1969, 185; Goldsworthy, 2006, 220-224). Through Dido's welcoming words to the Trojans, Virgil encapsulates the deep anxieties about fluid ethnic identity in a Mediterranean teeming with Phoenician sailors and settlers: 'Tros Tyriusque mihi nullo discrimine agetur' ('Trojan and Tyrian I shall treat with no distinction') (Virgil, 1935, I.574, 280-281). Chaucer, inheriting an anti-Punic poetic legacy, works to reinstall the ethnic distinctions that Dido so dangerously ignores.

\section{Grounding Dido}

In the House of Fame, Chaucer clearly indicates his literary historical selfidentification through 'his Roman masters' (Kiser, 1983, 17). Of the various metallic pillars that figure poetic schools, the majority mark Latin luminaries, with Statius, Ovid, Lucan, Claudian and Virgil standing unaccompanied (1419-1519). Sharing space with these Roman authorial monoliths is the distinctly non-Western Dido, the story of whose doomed affair with the treacherously transient Aeneas enlivens the temple of Venus that structurally precedes movement to the House of Fame (209-450). Dido's role in Chaucer's Romanized view of literary history is not only singular, but pivotal: her seduction and destruction frame the narrator's journey from antiquity to actuality. If Phoenician identity made Romans anxious about an itinerant and ambitious people who might attract others into its ethnic fold, then the Chaucer who takes up the mantle of Roman prestige mitigates such menace by creating a network of Dido-related images aimed at repressing the Carthaginian Other.

Anti-Punic Roman poets may have reductively portrayed Dido, but they uniformly presented her as the leader of an ethnic diaspora. In Virgil, for example, Queen Dido, while debating whether she should debase herself by asking to join the departing Trojans, reasons that she cannot, since she could not convince her Tyrian followers to uproot themselves again after their epic journey to Carthage (Virgil, 1935, IV.543-546, 432-433). Even in Ovid's frenetic voicing of a desperate Dido, the Carthaginian Queen speaks pragmatically about her triumphs as a diasporic leader, urging Aeneas to settle in the space she so painstakingly won and secured (Ovid, 1914, VII.11-24, 149-164). Classical Dido clearly rivaled Aeneas as both ruler and traveler.

Chaucer, however, both disables consideration of Dido's foundational journey, and obscures the location - and hence the historical specificity - of her realm. In the Legend of Good Women, Chaucer geographically dehistoricizes Dido: after her son arrives in 'Libye,' the faux-huntress Venus informs Aeneas that all women are hunters in Dido's 'regne [kingdom] of Libie' (958-993). Libya, typically understood by ancient geographers as a general region covering North Africa west of Egypt, offers only a vague setting for Dido's Carthage (Strabo, 1949, 
155-209; Herodotus, 1990, 293-295). Echoing the blurring of individual and land in Boccaccio's story of Libya in De Claris Mulieribus, Chaucer's Libyanized Dido is a virtual African indigene (Boccaccio, 2001, 50-51).

Chaucer combines an anti-historical impulse with such counter-geography. Exploiting the rhetorical device of occultatio, Chaucer's narrator says it would be idle to hear details about how Dido came to this 'regioun' (995-997) - this despite having just spent ample time lingering over such details as the cut of Venus's dress (972-975). Claiming that he does not 'lusteth' to 'ryme' of Dido's past (996), the Legend-narrator presents a Dido who may as well be a local - and nowhere does he give us a hint otherwise. Chaucer's Legend-narrator thus removes from his Ovidian source the vivid narratives of Dido's tense flight from her 'patri[a]' ['land'] and difficult foundation of Carthage in a hostile environment; instead, Chaucer roots Dido to the 'Punica ... humus' ['Punic soil'] where she encounters Aeneas (Ovid, 1914, VII.113-124, 139-140). Occluding Dido's travel-story, Chaucer erases her epic, ethno-genetic status, differentiating her from the well-traveled Aeneas and his divinely sanctioned invasion of Italy, while rendering her as static as the Libya in which she is counter-geographically situated. By grounding Dido, Chaucer here enacts Cato's fantasy of eradicating Phoenician maritime threats, transforming a sea-based empire into the soil with which Cato alone seemed comfortable. There is indeed gender and race 'overlap' as Chaucer frames Phoenician difference: Chaucer's erasure of Dido's exilic movement reduces the legendary, ethno-genetic heroine to just another native princess inhabiting a place visited by a male would-be founder (Cohen, 2003, 193).

\section{Of Pity and Boundary Fluidity}

Much as, according to Kathleen Davis, Chaucer responds to the medieval East's economic dynamism by having the modernizing Man of Law exterminate avatars of a dead, female past, so does Chaucer through Dido both invoke and contain a formerly dynamic Semitic antiquity (Davis, 2000, 113-117). Like the modern Orientalists who produced an East voiced entirely by Western fictions, Chaucer imagines an always already doomed Dido, who reinforces the impression that 'no Semite advanced in time beyond the development of a "classical" period' (Said, 1978, 234). As we have seen, the association of Phoenicians with boundary crossing channels anxieties about Carthage's maritime empire and its dependence upon merchant-settlers blending into disparate communities. Much as Romans imagined their own brand of ethnic mobility by picturing masculine aggressors like Romulus and Aeneas, Chaucer's racial fantasy of dangerously attractive Phoenicians is distinctly gendered. As an Eastern Other doubly distanced by her African locale, Dido serves in Chaucer's ongoing, imperialist project of using visions of antiquity to 'domesticate the alien woman' (Dinshaw, 1989, 86). 
8 Female lovers linked with ethnic crossing in the Legend include the Egyptian Cleopatra who woos Roman Antony $(588-$ 608), the Minoan Ariadne and Phaedra who both woo Greek Theseus (18862227) and the Colchian (Georgian) Medea who woos Greek Jason (15801679).
Though robbed of her legendary mobility by being grounded in Africa, Chaucer's Dido remains sexually dynamic. Dido's lust in the Legend of Good Women for the 'fayr' Aeneas highlights the Phoenician readiness to cross ethnic boundaries: 'for he was a straunger,' Aeneas appeals to a Carthaginian for whom 'ofte newe thing is swote [sweet]' (1073-1077). While exuding what James Simpson analyzes as a specifically Ovidian sympathy toward Dido as lover, Chaucer nevertheless aligns himself with Virgil's militarist, rather than Ovid's sentimental, vision of Punic culture (Simpson, 2002, 161-171). Whereas Ovid's Heroides mourns alongside women who fall in love with itinerant and double-dealing men, Chaucer's Legend of Good Women looks with Roman, anti-Punic eyes at female lovers associated with dangerous ethnic fluidity. ${ }^{8}$ Chaucer disciplines Dido's risky embrace of the Other, critiquing her foolish love of strangers and newness.

Describing pity in the Legend of Good Women, Aranye Fradenburg analyzes its intense, transformative power. Rather than merely indicating high-class sensibilities, pity marks a propensity to cross the line between the 'subject and the other' - and this marker is repeatedly associated with female agency and male benefits (Fradenburg, 2002, 187-188). In Virgil, Aeneas falls prey to pity's ethnically destabilizing joys - and it takes Jupiter and his messenger Mercury to wake Aeneas from his lovesickness, and remind him that he has a singularly Italian destiny - and not one that would allow him to linger and risk establishing a line of Trojan-Carthaginian kings (Virgil, 1935, IV.234-236, 410-411). Chaucer goes further in negating Dido's threat: Dido, who is so 'ful of pitee' as to 'trusten' men, gives up her kingdom - for 'she hath hir body and eek [also] hir reame [realm] yiven/Into his hond' (1280-1281). Moreover, Chaucer has Dido, who so proudly roots herself to her kingdom in Ovid, implore Aeneas, 'Let me with yow ryde!' (1316). Chaucer thus both invokes Dido's Phoenician predilection for movement, and diminishes her stature as a proud ruler by having pity compel her to stoop to ask to join Aeneas's diaspora as an uncrowned commoner.

As originally a heroic leader of a diaspora and as a lover whose pity inspires her to meld with those whom she desires, Dido, no less than Romulus or Aeneas, is an epic figure associated with the formation of what Anthony D. Smith calls an 'ethnie' - an ethnic group capable of transmitting collective memories rooted in a shared, if fluid, sense of homeland (Smith, 1986, 13-28). Recall that the 'historical' Dido supervised a journey from Tyre to Carthage that included acquiring young Cypriot women to intermarry with the youths in her fleet, as well as a priest of Jupiter. By supervising both the population's growth and its spiritual cohesion, all while traveling in search of a new home, Dido establishes herself as the sovereign manager of the boundaries defining Carthaginian ethnicity (Justinus, 1853, XVII.5; Desmond, 1994, 25-26). When a pitiful Dido dethrones herself, handing both her crown and dignity to an Aeneas who will not even take her along as a consort, Chaucer writes Dido out of the world of actual Mediterranean power. Pitifully grounded in North Africa, Chaucer's Dido merely poignantly voices the pastness of Phoenician dynamism in the Mediterranean. 


\section{Re-Annihilating Carthage}

Carthage fell because Rome was both relentless and ruthless. Rome's ceaselessly expanding war state savagely exploited Carthage's predisposition to negotiate (Goldsworthy, 2006, 338-339). Having capitulated to Rome's unreasonable demands, Carthage left itself virtually unarmed, with its hasty defenses incapable of resisting Rome's armies. As we have seen, Carthage's success as a maritime commercial empire generated powerful Roman anxieties about Phoenician difference, and Dido, with her deft negotiation of ethnic boundaries, came to embody Carthaginian otherness. Carthage's loose network of commercial ties and diplomatic flexibility unsettled Rome's more centralized, masculine vision of a militarist state - and so Carthage became the target both of Rome's armies and of its poets.

Chaucer makes himself a modern participant in this ancient war. In the Parliament of Fowls, Chaucer portrays the pair of Scipios who epitomize Rome's destruction of Punic civilization. Chaucer transplants the younger Scipio, destined to devastate Carthage, into Africa, where he recounts to the Numidian king Masinissa how his ancestor, Scipio Africanus, gave him a heavenly vision of 'Cartage' (41-44). Chaucer moves from Scipio the Younger - who after 17 days of burning and plundering transformed Carthage into a virtual desert - to the elder Scipio, who defeated Hannibal at Zama, ending decades of Carthaginian destabilization of Roman Italy (Goldsworthy, 2006, 352-354, 220-224). The Scipios' lofty lesson of 'comun profit' (47) aligns Chaucer's England with Roman empire - for Chaucer may still pursue the ethical path modeled by the Scipios, unlike the Carthaginians whose historical development was decisively ended.

In the network of dream-vision references imagining Carthaginian otherness, Chaucer's most chilling image aestheticizes Carthage's destruction. In stepping into a desert after having marveled at Dido's story in a sumptuous locale, the narrator of the House of Fame retraces a historical erasure: the movement from Venus's image-saturated 'temple' (130) to a 'felde' of 'sonde' ['sand'] (482-486) binds the worlds of art and history, as vivid ancient life gives way to the wasteland that was once Dido's empire. Though the narrator does not specify the desert's location, he indicates it indirectly by comparing its sands to the 'desert of Libye' (487-488), in which vague region the Legend-narrator confines Dido. This desert epitomizes Chaucer's participation in Rome's anti-Punic campaigns. Having grounded Carthage's founder, and stripped her of the ethno-genetic backstory that links her with fellow traveler and founder-figure Aeneas, Chaucer moves from Dido's legend to the site of Rome's genocidal removal of Carthaginians from history. Chaucer's presentation of this dehistoricized Dido in the 'olde werk' of Venus's temple in the House of Fame (127), coupled with his recapitulation of Carthage's annihilation, consigns an objectified Phoenician culture to a timeless, aestheticized antiquity that serves as an uncanny prelude to the dynamics of racialization that define Western modernity. 


\section{About the Author}

Randy P. Schiff is Associate Professor of English and the Director of Undergraduate Studies in the English Department at University at Buffalo, SUNY. He is the author of Revivalist Fantasy: Alliterative Verse and Nationalist Literary History (Ohio State, 2011), as well as of essays on Middle English, Middle Scots and Old French literature. He is currently preparing a monograph on the poetics of territory in medieval romance (E-mail: rpschiff@buffalo.edu).

\section{References}

Aubet, M.E. 2001. The Phoenicians and the West: Politics, Colonies and Trade, trans. M. Turton. 2nd edn. Cambridge, UK: Cambridge University Press.

Barth, F., ed. 1998. Pathan Identity and Its Maintenance. In Ethnic Groups and Boundaries: The Social Organization of Cultural Difference, 117-134. Long Grove, IL: Waveland Press.

Bernal, M. 1987. Black Athena: The Afroasiatic Roots of Classical Civilization, Vol. 1: The Fabrication of Ancient Greece, 1785-1985. New Brunswick, NJ: Rutgers University Press.

Boccaccio, G. 2001. Famous Women, ed. and trans. V. Brown. Cambridge, MA: Harvard University Press.

Casson, L. 1991. The Ancient Mariners: Seafarers and Sea Fighters of the Mediterranean in Ancient Times. Princeton, NJ: Princeton University Press.

Cato and Varro. 1935. On Agriculture, ed. J. Henderson, trans. W.D. Hooper and H.B. Ash. Loeb Classical Library. Cambridge, MA: Harvard University Press.

Chaucer, G. 1987. The Riverside Chaucer, eds. L.D. Benson et al. 3rd edn. Boston, MA: Houghton Mifflin.

Cohen, J.J. 2003. Medieval Identity Machines. Minneapolis, MN: University of Minnesota Press.

Crawford, M. 1986. Early Rome and Italy. In The Oxford History of the Roman World, ed. J. Boardman et al., 13-49. Oxford, UK: Oxford University Press.

Davis, K. 2000. Time Behind the Veil: The Media, the Middle Ages, and Orientalism Now. In The Postcolonial Middle Ages, ed. J.J. Cohen, 105-122. Basingstoke, UK: Palgrave.

Davis, K. 2008. Periodization and Sovereignty: How Ideas of Feudalism and Secularization Govern the Politics of Time. Philadelphia, PA: University of Pennsylvania Press.

Desmond, M. 1994. Reading Dido: Gender, Textuality, and the Medieval 'Aeneid'. Minneapolis, MN: University of Minnesota Press.

Dinshaw, C. 1989. Chaucer's Sexual Poetics. Madison, WI: University of Wisconsin Press.

Fabian, J. 1983. Time and the Other: How Anthropology Makes Its Object. New York: Columbia University Press.

Fradenburg, L.O.A. 2002. Sacrifice Your Love: Psychoanalysis, Historicism, Chaucer. Minneapolis, MN: University of Minnesota Press.

Gates, H.L. Jr. 1985. Writing 'Race' and the Difference It Makes. Critical Inquiry 12(1): 1-20. Goldsworthy, A. 2006. The Fall of Carthage. London: Phoenix. 
Hahn, T. 2001. The Difference the Middle Ages Makes: Color and Race before the Modern World. Journal of Medieval and Early Modern Studies 31(1): 1-37.

Heng, G. 2003. Empire of Magic: Medieval Romance and the Politics of Cultural Fantasy. New York: Columbia University Press.

Herodotus. 1990. Histories, Books I and II, ed. G.P. Goold, trans. A.D. Godley. Loeb Classical Library. Cambridge, MA: Harvard University Press.

Justinus, M.J. 1853. Epitome of the 'Philippic History' of Pompeius Trogos, trans. J.S. Watson. London: Henry G. Bohn.

Kiernan, B. 2007. Blood and Soil: A World History of Genocide and Extermination from Sparta to Darfur. New Haven, CT: Yale University Press.

Kinoshita, S. 2009. Medieval Mediterranean Literature. PMLA 124(2): 600-608.

Kiser, L. 1983. Telling Classical Tales: Chaucer and the 'Legend of Good Women'. Ithaca, NY: Cornell University Press.

Livy. 1925. Ab Urbe Condita, eds. E. Capps et al., trans. B.O. Foster. Loeb Classical Library. Cambridge, MA: Harvard University Press.

Markoe, G.E. 2000. Phoenicians (Peoples of the Past). Berkeley, CA: University of California Press.

Menocal, M.R. 1987. The Arabic Role in Medieval Literary History: A Forgotten Heritage. Philadelphia, PA: University of Pennsylvania Press.

Olson, C. 1983. The Maximus Poems, ed. G.F. Butterick. Berkeley, CA: University of California Press.

Ovid. 1914. Heroides, eds. T.E. Page and W.H.D. Rouse, trans G. Showerman. Loeb Classical Library. Cambridge, MA: Harvard University Press.

Picard, G.C. and C. Picard. 1969. The Life and Death of Carthage: A Survey of Punic History and Culture from Its Birth to the Final Tragedy, trans. D. Collon. New York: Taplinger.

Said, E.W. 1978. Orientalism. New York: Vintage.

Silius, I. 1934. Punica, ed. J. Henderson, trans. J.D. Duff. 2 vols. Loeb Classical Library. Cambridge, MA: Harvard University Press.

Simpson, J. 2002. Reform and Cultural Revolution. The Oxford English Literary History, Vol. 2. Oxford, UK: Oxford University Press.

Smith, A.D. 1986. The Ethnic Origins of Nations. Oxford, UK: Blackwell.

Strabo. 1949. Geography, Book 17, ed. G.P. Goold, trans. H.L. Jones. Loeb Classical Library. Cambridge, MA: Harvard University Press.

Virgil. 1935. The Aeneid, ed. G.P. Goold, trans. H.R. Fairclough. Loeb Classical Library. Cambridge, MA: Harvard University Press. 